Portland State University

PDXScholar

Engineering and Technology Management

Faculty Publications and Presentations

9-1-2016

\title{
Technology Planning for Emerging Business Model and Regulatory Integration: The Case of Electric Vehicle Smart Charging
}

Kelly Cowan

Portland State University

Tugrul U. Daim

Portland State University, tugrul@etm.pdx.edu

Follow this and additional works at: https://pdxscholar.library.pdx.edu/etm_fac

Part of the Operations Research, Systems Engineering and Industrial Engineering Commons Let us know how access to this document benefits you.

\section{Citation Details}

Cowan, Kelly and Daim, Tugrul U., "Technology Planning for Emerging Business Model and Regulatory Integration: The Case of Electric Vehicle Smart Charging" (2016). Engineering and Technology Management Faculty Publications and Presentations. 104.

https://pdxscholar.library.pdx.edu/etm_fac/104

This Article is brought to you for free and open access. It has been accepted for inclusion in Engineering and Technology Management Faculty Publications and Presentations by an authorized administrator of PDXScholar. Please contact us if we can make this document more accessible: pdxscholar@pdx.edu. 


\title{
Technology Planning for Emerging Business Model and Regulatory Integration: The Case of Electric Vehicle Smart Charging
}

\author{
Kelly Cowan, Tugrul U Daim \\ Dept. of Engineering and Technology Management, Portland State University, Portland OR - USA
}

\begin{abstract}
Smart grid has been described as the Energy Internet: Where Energy Technology meets Information Technology. The incorporation of such technology into vast existing utility infrastructures offers many advantages, including possibilities for new smart appliances, energy management systems, better integration of renewable energy, value added services, and new business models, both for supplyand demand-side management. This paper proposes to build upon existing roadmapping processes by considering an integrated set of factors, including policy issues, that are specifically tuned to the needs of smart grid and have not generally been considered in other types of roadmapping efforts. It will also incorporate expert judgment quantification to prioritize factors, show the pathways for overcoming barriers and achieving benefits, as well as discussing the most promising strategies for achieving these goals.
\end{abstract}

\section{LITERATURE REVIEW}

Literature from several key literature streams has been reviewed and research gaps were identified. The first key area analyzed was the Technology Roadmapping literature. The following research gaps are summarized on the table 1 below.

The second key area discussed was the Smart Grid and Electric Vehicle literature. The following research gaps are summarized on the table 2 below.

The third key area discussed was the Resource Planning literature. The following research gaps are summarized on the table 3

The following sections summarizes the Research Gaps, Research Goals and Research Questions determined after performing all the analysis up to this point in this study.

FIGURE 1 TECHNOLOGY ROADMAPPING LITERATURE GAPS

\begin{tabular}{|l|l|l|}
\hline \multicolumn{1}{|c|}{ Research Concept } & \multicolumn{1}{c|}{ References } \\
\hline $\begin{array}{l}\text { Various processes developed for applying } \\
\text { TRM in current and emerging industries }\end{array}$ & {$[1-5],[6-15],[16-25]$} & \multicolumn{1}{c|}{ Research Gaps } \\
$\begin{array}{l}\text { Several methods integrate aspects of } \\
\text { business modeling with TRM }\end{array}$ & {$[18,19],[21,22],[26-31],[32-36],[37-50]$,} & $\begin{array}{l}\text { Method is needed to integrate business } \\
\text { modeling, policy, and regulatory factors } \\
\text { into TRM for the utility industry }\end{array}$ \\
$\begin{array}{l}\text { Few studies consider policy dimensions of } \\
\text { TRM or regulatory frameworks, particularly } \\
\text { in the utility industry }\end{array}$ & {$[51,52]$} \\
$\begin{array}{l}\text { TRM generally used at company-, industry-, } \\
\text { and national-level, rather than incorporating } \\
\text { regional utility concerns }\end{array}$ & {$[55-63][53,54,64-67],[32],[34],[37]$} \\
$\begin{array}{l}\text { More work also needed prioritizing R\&D, } \\
\text { acquisition, and barriers }\end{array}$ & {$[31-43],[68-75]$} & $\begin{array}{l}\text { TRM goals must align with regional-level } \\
\text { factors for utility industry and associated } \\
\text { products }\end{array}$ \\
\end{tabular}

FIGURE 2 SMART GRID \& ELECTRIC VEHICLE LITERATURE GAPS

\begin{tabular}{|l|l|l|}
\hline \multicolumn{1}{|c|}{ Research Concept } & \multicolumn{1}{|c|}{ References } & \multicolumn{1}{c|}{ Research Gaps } \\
\hline $\begin{array}{l}\text { Smart grid roadmap literature typically } \\
\text { focuses on operational plans for utilities } \\
\text { as opposed to regional energy planning }\end{array}$ & {$[76],[77],[78-83],[84,85],[86-92],[93]$} & $\begin{array}{l}\text { Smart grid planning literature could } \\
\text { benefit from better alignment with } \\
\text { technology roadmapping literature }\end{array}$ \\
$\begin{array}{l}\text { Generally do not consider regional goals } \\
\text { and structural barriers to business and } \\
\text { market adoption }\end{array}$ & {$[94-103],[104-107],[108,109],[55,59-62$,} & $\begin{array}{l}\text { Process needed to create roadmaps for } \\
\text { smart grid technologies that integrate } \\
\text { business modeling with regulatory } \\
\text { factors and policy factors to meet } \\
\text { regional energy planning objectives } \\
\text { and overcome structural barriers }\end{array}$ \\
$\begin{array}{l}\text { No current SG roadmaps for Oregon or } \\
\text { the Pacific Northwest. }\end{array}$ & {$[95,96,98,99]$} & $\begin{array}{l}\text { Customization needed to develop } \\
\text { technology roadmapping processes for } \\
\text { EV smart charging systems }\end{array}$ \\
\hline $\begin{array}{l}\text { Significant planning also needed for } \\
\text { electric EV smart charging roadmap }\end{array}$ & {$[56-58],[117],[9-15],[26],[118-121]$} &
\end{tabular}


2016 Proceedings of PICMET '16: Technology Management for Social Innovation

FIGURE 3 RESOURCE PLANNING \& POLICY LITERATURE GAPS

\begin{tabular}{|c|c|c|}
\hline Research Concept & References & Research Gaps \\
\hline $\begin{array}{l}\text { Strategic alignment of business model } \\
\text { and policy frameworks particularly } \\
\text { important for regulated industries like } \\
\text { electric utilities }\end{array}$ & $\begin{array}{l}\text { [122], [123], [124], [125-131], [84, 85, } 94- \\
97],[101],[88,89],[55,59,110-112], \\
{[113],[132,133]}\end{array}$ & $\begin{array}{l}\text { Need to incorporate an unde } \\
\text { of utility regulation and plan } \\
\text { processes to create strategic } \\
\text { between business models an } \\
\text { frameworks }\end{array}$ \\
\hline $\begin{array}{l}\text { Unique regional energy policy planning } \\
\text { issues in Pacific Northwest due to } \\
\text { regulatory frameworks }\end{array}$ & $\begin{array}{l}{[98-100,102],[92],[108,109],[60-62],[32-} \\
34],[115]\end{array}$ & $\begin{array}{l}\text { TRM methods need to be ad } \\
\text { unique regulatory framewor } \\
\text { regional utility industries }\end{array}$ \\
\hline $\begin{array}{l}\text { Multiple perspectives view is critical for } \\
\text { creating robust planning models in the } \\
\text { utility industry }\end{array}$ & {$[1-3],[56-58],[69-74],[134,135]$} & $\begin{array}{l}\text { Strong need for robust, mult } \\
\text { perspective planning model } \\
\text { utility industry that create st } \\
\text { alignment between business } \\
\text { policy, and regulatory requi }\end{array}$ \\
\hline Research Gaps & Research Goal & $\begin{array}{l}\text { Research } \\
\text { Questions }\end{array}$ \\
\hline $\begin{array}{c}\text { Lack of integration between } \\
\text { technology planning, business } \\
\text { modeling, regulatory } \\
\text { development, and regional } \\
\text { energy policy }\end{array}$ & \multirow{4}{*}{$\begin{array}{l}\text { Develop an integrated } \\
\text { planning process to address } \\
\text { technology development, } \\
\text { emerging business models, } \\
\text { policy, and regulatory issues } \\
\text { for smart electric vehicle to } \\
\text { grid system to meet regional } \\
\text { utility industry needs in the } \\
\text { PNW }\end{array}$} & $\begin{array}{l}\text { RQ1: What are the highest } \\
\text { priority technologies, gaps \& } \\
\text { barriers for creating V2G } \\
\text { systems that meet business, } \\
\text { regulatory, and regional } \\
\text { energy policy objectives? }\end{array}$ \\
\hline $\begin{array}{l}\text { Lack of Comprehensive Plans } \\
\text { for V2G PNW }\end{array}$ & & \multirow{2}{*}{$\begin{array}{l}\text { RQ2: Is TRM an appropriate } \\
\text { tool for understanding } \\
\text { technology, business, } \\
\text { regulatory, and regional } \\
\text { energy policy objectives }\end{array}$} \\
\hline $\begin{array}{l}\text { Need to identify and prioritize } \\
\text { requirements for development }\end{array}$ & & \\
\hline $\begin{array}{l}\text { technology plans to meet } \\
\text { emerging business, } \\
\text { regulatory, and regional } \\
\text { energy policy objectives }\end{array}$ & & $\begin{array}{l}\text { RQ3:Can TRM be } \\
\text { combined with business } \\
\text { modeling and prioritization } \\
\text { to better understand key } \\
\text { requirements for creating a } \\
\text { plan for V2G in the PNW } \\
\text { that meets business, } \\
\text { regulatory, and regional } \\
\text { energy policy objectives? }\end{array}$ \\
\hline
\end{tabular}

Figure 4: Summary of Research Gaps, Goals, and Questions

\section{METHODOLOGY AND RESULTS}

The following diagram outlines the key steps that are expected to be needed to conduct the research described in the paper up to this point.

The first step was to establish two expert panels that were required to conduct the initial research. The following criteria were used for the selection of experts who will provide judgment data for this study. Experts were generally management-level professionals with at least five years of experience and a degree in a relevant discipline to the research topic being discussed. The members of each panel were selected to provide balance and to represent a range of viewpoints. The goal of the panel is span multiple industries and disciplines to achieve a cross section designed to eliminate bias.
Data Collection will be conducted in a series of 5 phases: Phases 1 through 4, as well as a Phase 0 for instrument testing. These phases are listed on the table below and then described in further detail in this section. The experts were asked to participate in up to three workshops, which had a duration of approximately 2 hours for the first two workshops and about 4 hours for the final workshop.

In the first workshop, the stakeholder information was translated into drivers of value production for products and services for a technology roadmap. Product and service performance factors necessary to satisfy these drivers will then be identified. Current products and services that meet existing performance requirements will be identified, along with any gaps or deficiencies in being able to meet these requirements. 


\begin{tabular}{|c|c|c|c|c|c|}
\hline & & Phase 1 & Phase 2 & Phase 3 & Phase 4 \\
\hline Documents & $\begin{array}{c}\text { Technology } \\
\text { Planning for } \\
\text { Business, } \\
\text { Regulatory \& } \\
\text { Policy Integration }\end{array}$ & $\begin{array}{c}\text { Start-up Business } \\
\text { Model } \\
\text { Development }\end{array}$ & Industry Analysis & $\begin{array}{l}\text { Prioritization \& } \\
\text { Verification }\end{array}$ & $\begin{array}{l}\text { Analysis \& } \\
\text { Synthesis }\end{array}$ \\
\hline Methods & $\begin{array}{l}\text { Research Design } \\
\text { Diagram }\end{array}$ & $\begin{array}{l}\text { Business Concept } \\
\text { Development }\end{array}$ & $\begin{array}{c}\text { Modified } 5 \text { Forces } \\
\text { (Reg Indus), Profit } \\
\text { Modeling }\end{array}$ & $\begin{array}{l}\text { TRM Constrcution } \\
\text { \& Prioritization }\end{array}$ & $\begin{array}{c}\text { Integrated TRM \& } \\
\text { Analysis }\end{array}$ \\
\hline Processes & $\begin{array}{c}\text { Literature, Experts } \\
\qquad(6-8)\end{array}$ & $\begin{array}{l}\text { Literature, Email } \\
\text { Virtual Panel (6-8) }\end{array}$ & $\begin{array}{l}\text { Literature, Email } \\
\text { Virtual Panel (6-8) }\end{array}$ & Workshop (12-16) & $\begin{array}{c}\text { Research } \\
\text { Synthesis, Expert } \\
\text { Feedback (12-18) }\end{array}$ \\
\hline Description & $\begin{array}{c}\text { Utility Experts, Pol } \\
\text { Anlyts, EV/V2G } \\
\text { Bus \& Tech } \\
\text { Experts } \\
\end{array}$ & $\begin{array}{l}\text { Utility Execs, Pol } \\
\text { Anlyts, EV/V2G } \\
\text { Bus Experts }\end{array}$ & $\begin{array}{l}\text { Utility Execs, Pol } \\
\text { Anlyts, EV/V2G } \\
\text { Bus Experts }\end{array}$ & $\begin{array}{c}\text { Utility Experts, Pol } \\
\text { Anlyts, EV/V2G } \\
\text { Bus \& Tech } \\
\text { Experts } \\
\end{array}$ & $\begin{array}{l}\text { Data Analysis, } \\
\text { Validation \& } \\
\text { Conclusions }\end{array}$ \\
\hline Validation & $\begin{array}{c}\text { Content \& Face } \\
\text { Validity Tools }\end{array}$ & $\begin{array}{c}\text { Content Validity } \\
\text { Tools }\end{array}$ & $\begin{array}{c}\text { Content Validity } \\
\text { Tools }\end{array}$ & $\begin{array}{c}\text { Criteria Validity } \\
\text { Tools }\end{array}$ & $\begin{array}{c}\text { Criteria Validity } \\
\text { Tools }\end{array}$ \\
\hline Examples & $\begin{array}{l}\text { Complete B\&R } \\
\text { Model and } \\
\text { Complete } \\
\text { Prioritized TRM }\end{array}$ & $\begin{array}{c}\text { Stakeholder- } \\
\text { Objective Matrix, } \\
\text { Business Sub- } \\
\text { Models, Business } \\
\text { Summary, } \\
\text { Stakeholder } \\
\text { Perspectives, and } \\
\text { Business Model } \\
\text { Overview }\end{array}$ & $\begin{array}{l}\text { Modified 5 Forces } \\
\text { Model, Business- } \\
\text { Stakeholder } \\
\text { Alternatives } \\
\text { Matrix, Industry } \\
\text { Factor Alternatives } \\
\text { Matrix, Statics \& } \\
\text { Dynamic Business } \\
\text { Models }\end{array}$ & $\begin{array}{l}\text { Grouped Drivers, } \\
\text { Impact Matrices, } \\
\text { Initial TRM and } \\
\text { Prioritization }\end{array}$ & $\begin{array}{c}\text { Final Integrated } \\
\text { TRM, Analysis or } \\
\text { Alternatives and } \\
\text { Priorities }\end{array}$ \\
\hline
\end{tabular}

Figure 5 Research Outline

The second workshop analyzed emerging technologies and compared them to required technology characteristics that are expected to be important for those technologies. Potential solutions were examined to see how they may meet required characteristics. This information will then be used to determine if gaps exist in technology requirements and the present state of development for these technologies. If gaps are identified, then descriptions of R\&D programs necessary to fill these gaps will be created.

In the third workshop, the current market environment and policy environment with respect to EVSC was examined. If any market or policy elements negatively impacted product or service performance in the first workshop, items on the Solutions layer show possible ways to address such market or policy barriers. Specific mitigation strategies, such as policy changes or market incentives may then be considered to overcome these barriers.

The output of the second and third workshops were then analyzed in order to determine which technology-product gaps are the most significant to address and which market and policy barriers are the important as well. The end result of this is an EVSC roadmap which will help stakeholders understand the most critical elements that are necessary to achieve goals. Potential outcomes can then be analyzed, along with prioritization scores to determine the main factors necessary for key stakeholders to achieve desired outcomes and the factor dependencies required. More detail on the prioritization process will be described in the next section, along with the information needed to construct the technology roadmap.

The following tables povide a set of tools designed to assist with the roadmap development and prioritization process. A series of data collection instruments, matrixes, and prioritization tools are presented to perform various stages of roadmap construction and assessment of the various input factors. 


\begin{tabular}{|c|l|c|l|}
\hline$\#$ & \multicolumn{1}{|c|}{ Grouped Market Drivers } & Priority & \multicolumn{1}{c|}{ Notes and Constituent Drivers } \\
\hline DM1 & Energy Management / Emissions \& Sustainability & $\checkmark \checkmark \checkmark$ & Green consumers, carbon footprint, managing fuel costs. Linked to DM3 \\
\hline DM2 & Improved EV Battery Performance & $\checkmark \checkmark \checkmark V$ & Low battery costs, high capacity / range, fast charge, long life \\
\hline DM3 & Reduced Vehicle Costs & $\checkmark \checkmark \checkmark V$ & Linked to DM2 \\
\hline DM4 & Consumer EV / Charging Incentives & $\checkmark \checkmark \checkmark V$ & Subsidies, benefits, financing \\
\hline
\end{tabular}

\begin{tabular}{|c|c|c|c|}
\hline$\#$ & Grouped Business Drivers & Priority & Notes and Constituent Drivers \\
\hline DB1 & $\begin{array}{l}\text { Transactive Energy Business Standards } \\
\text { Development }\end{array}$ & $\sqrt{ } \downarrow \checkmark$ & Linked to Go8, PC2, S2-6, B5 \\
\hline DB2 & Charging Infrastructure Requirements & $\mathrm{V} \mathrm{V}$ & Linked to GP5, Go1, Go6-9, Gp3-4 \\
\hline DB3 & Business Partnerships and Policies & $\sqrt{ } \sqrt{ }$ & Linked to DB1, PC2-3, Go2, S5-6 \\
\hline DB4 & Need for grid support services, enhanced stability & $\checkmark \checkmark$ & Linked to DB1, DB3, DR5 \\
\hline DB5 & Business Ownership Structures and Financing & $\sqrt{ } \backslash \downarrow \downarrow$ & Linked to DP7 \\
\hline
\end{tabular}

Figure 6: Grouped Drivers - Market and Business Source: $[2,31,38]$

\begin{tabular}{|c|c|c|c|}
\hline \# & Grouped Policy Drivers & Priority & Notes and Constituent Drivers \\
\hline DP1 & Reducing Vehicle Emissions & $\sqrt{ } \sqrt{ } \downarrow$ & Linked to DP3-6, DP8 \\
\hline DP2 & Vehicle Fuel Economy / Energy Efficiency & $\sqrt{ } \sqrt{ } \sqrt{ }$ & Linked to DP3-5 \\
\hline DP3 & State / Regional Energy Planning Goals & $\sqrt{ } \sqrt{ }$ & Linked to DP1-2, DP4-6, DP8 \\
\hline DP4 & State / Regional Emissions Policies, Plans & $\sqrt{ } \sqrt{ }$ & Linked to DP1-3, DP4-6 \\
\hline DP5 & Electric Vehicle Adoption Goals, plans & $\sqrt{ } \sqrt{ }$ & Linked to DP1-4, DP6-9, DR1-5 \\
\hline DP6 & RPS and need for Renewable Energy Integration & $\sqrt{ } \sqrt{ }$ & Linked to DP1-5, DP7-9,DR 3, DR5 \\
\hline DP7 & Business EV / Charging Incentives & $\sqrt{ } \sqrt{ } \downarrow V$ & Linked to DR2-5, DB5 \\
\hline DP8 & Renewable Energy Integration Needs & $\sqrt{ } \sqrt{ } \sqrt{ }$ & Linked to DP6, DP9 \\
\hline DP9 & Charging Infrastructure Upgrades and Investment Needs & $\sqrt{ } \backslash \sqrt{ } \downarrow$ & Linked toDP6-8, DP3-5, DR4-5 \\
\hline
\end{tabular}

\begin{tabular}{|c|l|c|l|}
\hline$\#$ & \multicolumn{1}{|c|}{ Grouped Regulatory Drivers } & Priority & Notes and Constituent Drivers \\
\hline DR1 & Zero Emissions Vehicle Sales Mandate (ZEV / PZEV) & $\checkmark \checkmark \checkmark$ & $\begin{array}{l}\text { ZEV sales requirement in CA and other states. Linked to DP1, DP4, } \\
\text { DP5 }\end{array}$ \\
\hline DR2 & Regulation \& Legislation on EV charging rates and processes & $\checkmark \checkmark \checkmark \checkmark$ & Linked to DP5,DP7,DR4-5 \\
\hline DR3 & Transactive Energy Standards Development & $\checkmark \checkmark \checkmark$ & Linked to DP6-9, DR4-5 \\
\hline DR4 & Charging Hardware / Software Standardization & $\checkmark \checkmark \checkmark \checkmark$ & Linked to DP5, DP8, DP9 \\
\hline DR5 & Plans for Grid Modernization and Stability & $\checkmark \checkmark \checkmark \checkmark$ & Linked to DP-56, DP8-9 \\
\hline & & & \\
\hline
\end{tabular}

Figure 7: Grouped Drivers - Regulatory and Policy

Source: $[2,31,38]$ 


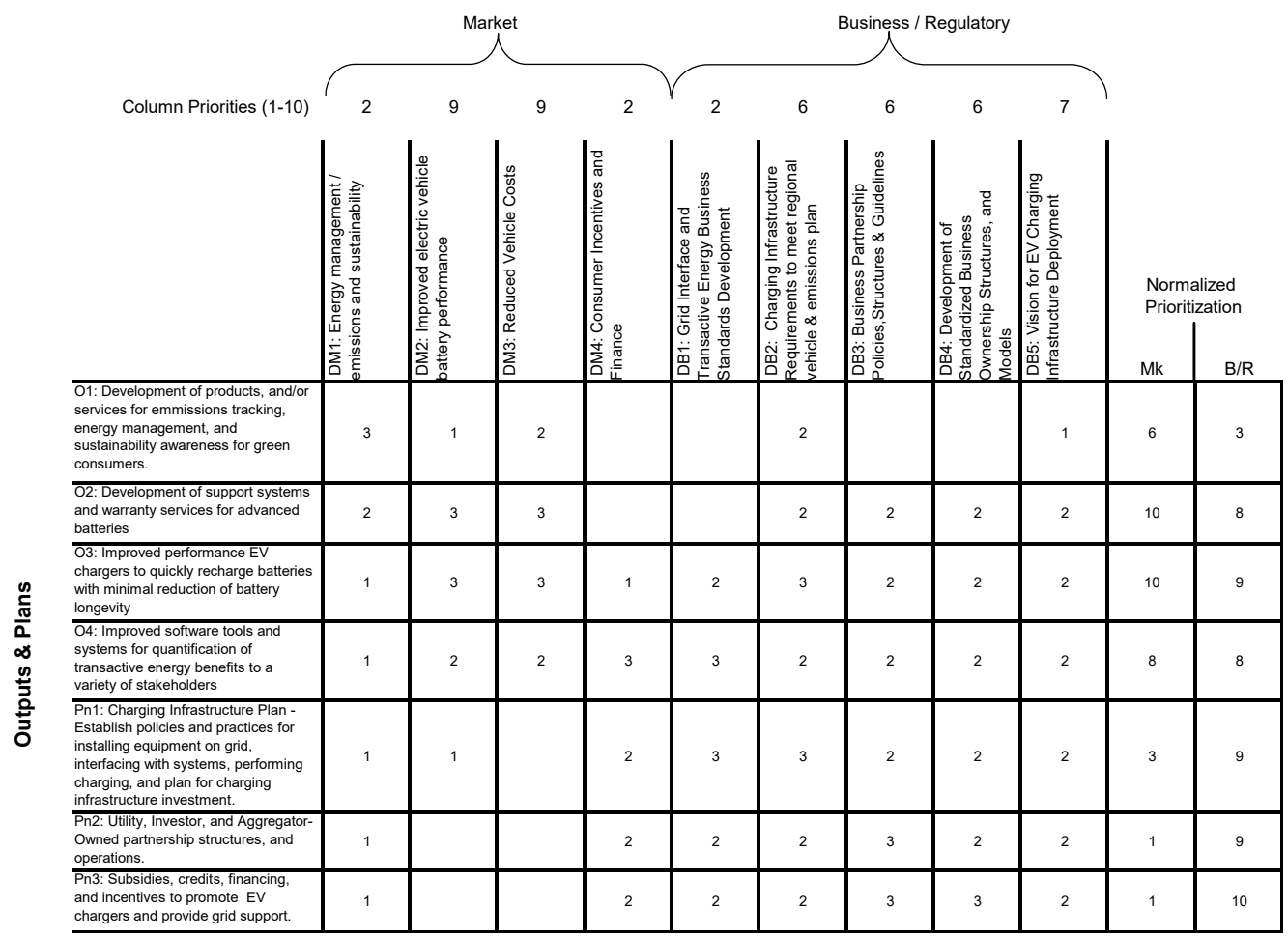

Figure 8: Market, Business, Regulatory \& Policy Drivers vs. Plans and Outputs Source: $[2,31,38]$

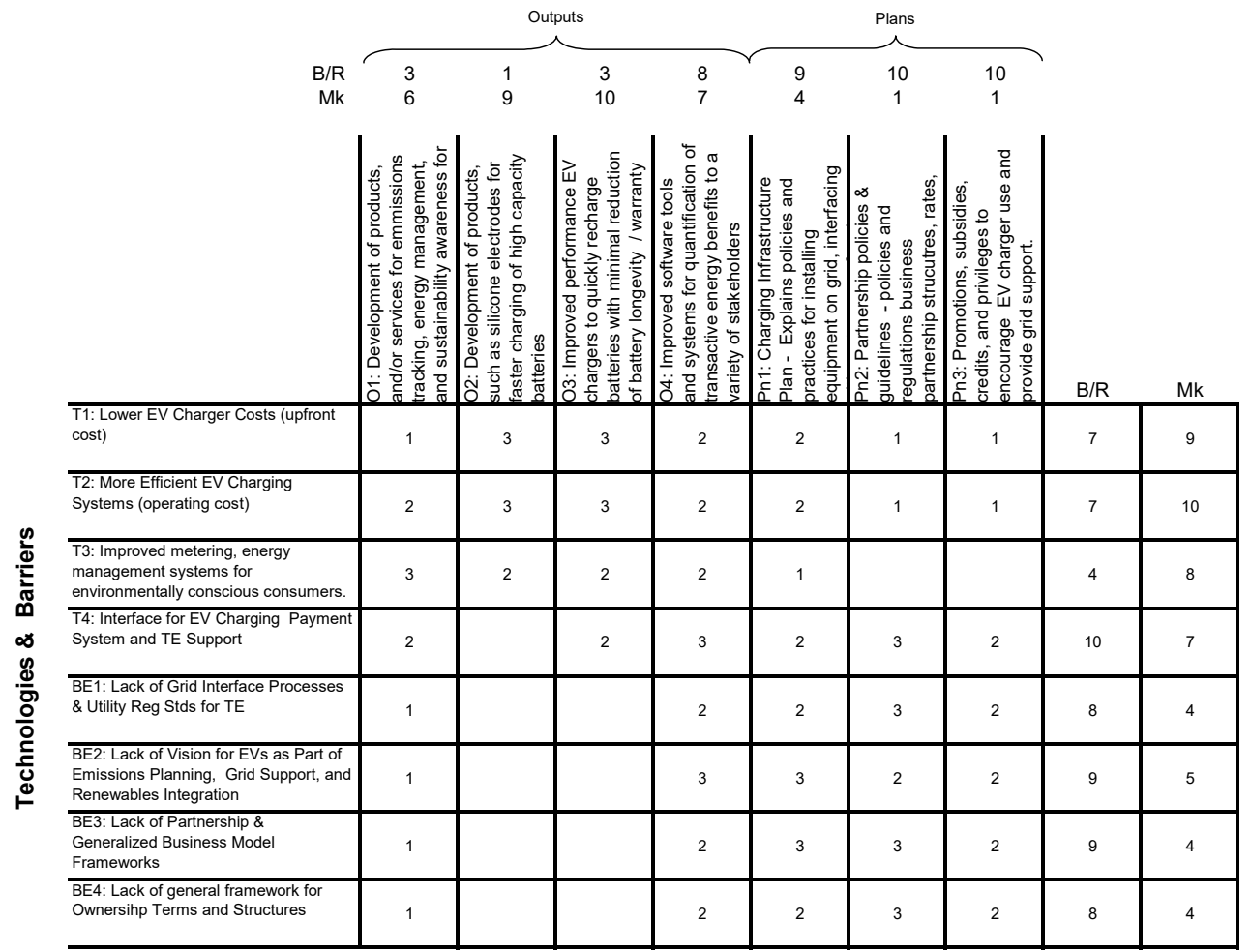

Figure 9: Plans \& Outputs vs. Technologies \& Barriers Source: $[2,31,38]$ 


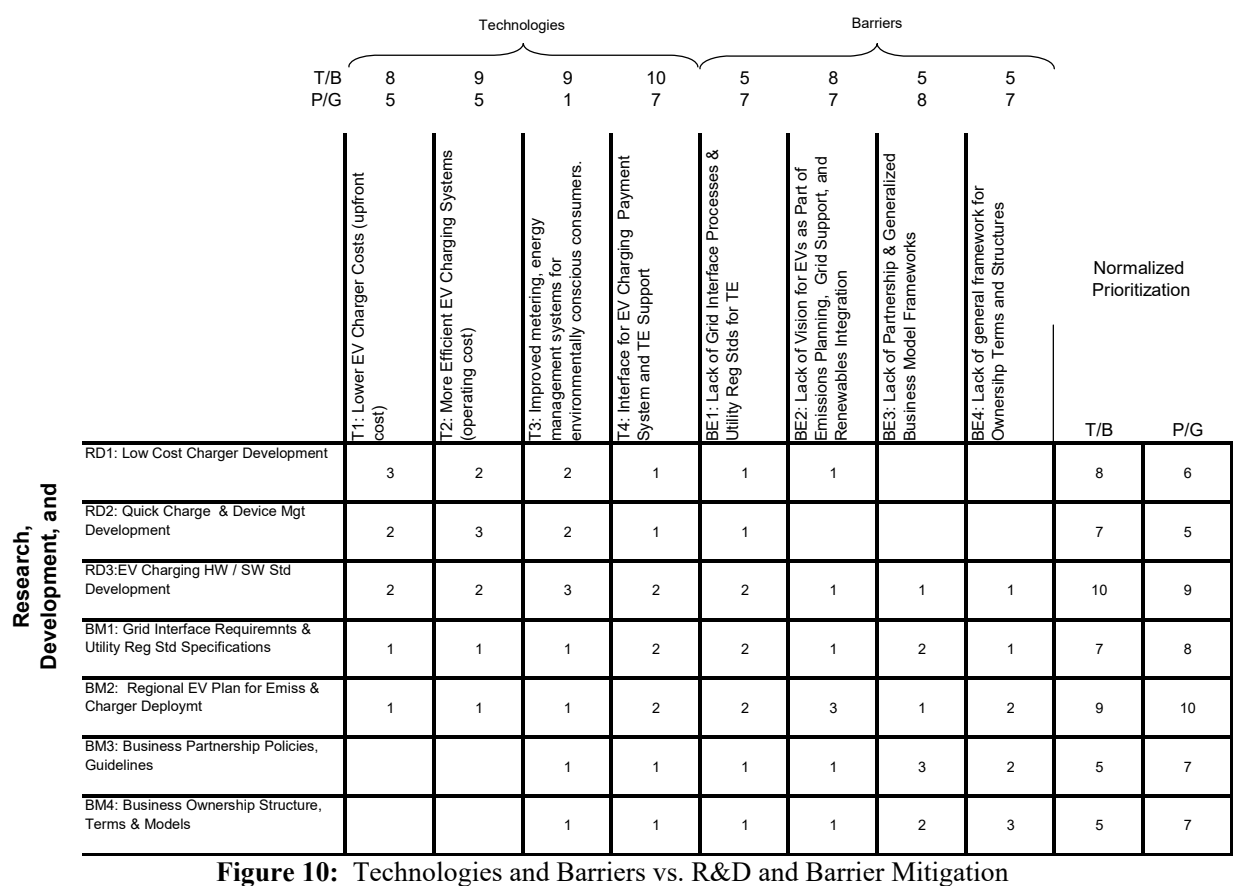

After finishing the initial data gathering and prioritization processes, a series of roadmap models were constructed incorporating the data. Several types of roadmaps were created to examine different aspects of this research. First, an overall roadmap was created that showed the combined effect of business, government, consumer, and market factors over the entire 10-year time span of the roadmap. This roadmap is consists of three parts, representing different set of layers on the roadmap. Part 1 is composed of three layers: (1) Drivers;
(2) Gaps, Goals, and Products; and (3) Product Characteristics and Barriers. Part 2 contains two layers: (1) a continuation of Product Characteristics and Barriers; and (2) Solutions, which involve Technology, Business Model, Market, Regulatory, and Barrier Mitigation. Part 3 has 1 layer, which is a continuation of the Solutions layer started in Part 2. Parts 1, 2, and 3 or the overall roadmap are shown in the following figures.

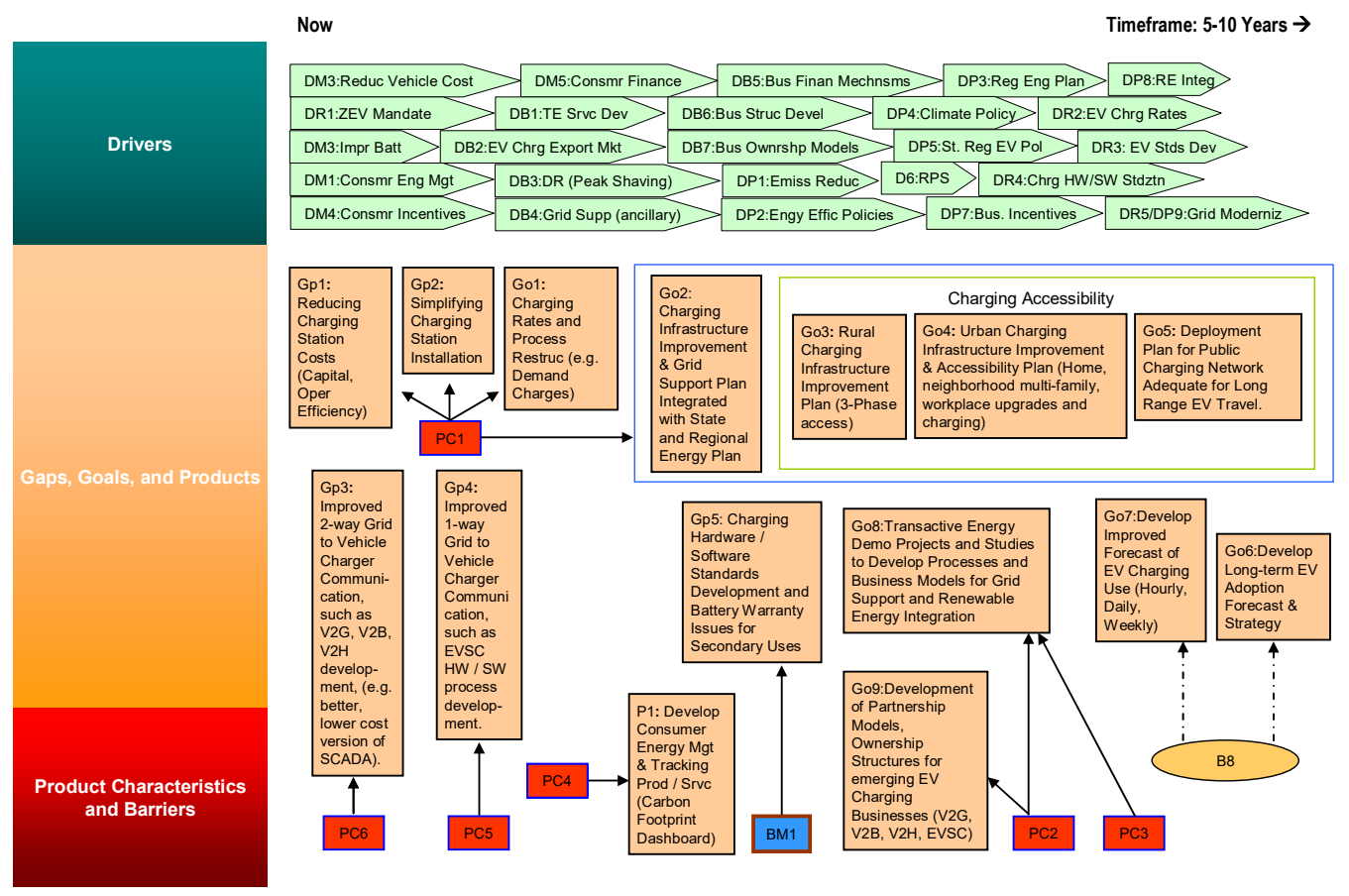

Figure 11: Integrated TRM Model: Electric Vehicle Charging - Part 1 
As previously mentioned, Part 1 of the overall roadmap represents the top 3 layers, which consists of Drivers, Gaps, Goals, and Products, as well as Product Characteristics and Barriers. Part 2 of the roadmap then shows the next 2 layers, starting with a continuation of Product Characteristics and Barriers, and then the initial portion of the Solutions layer.

Part 2 is shown below.
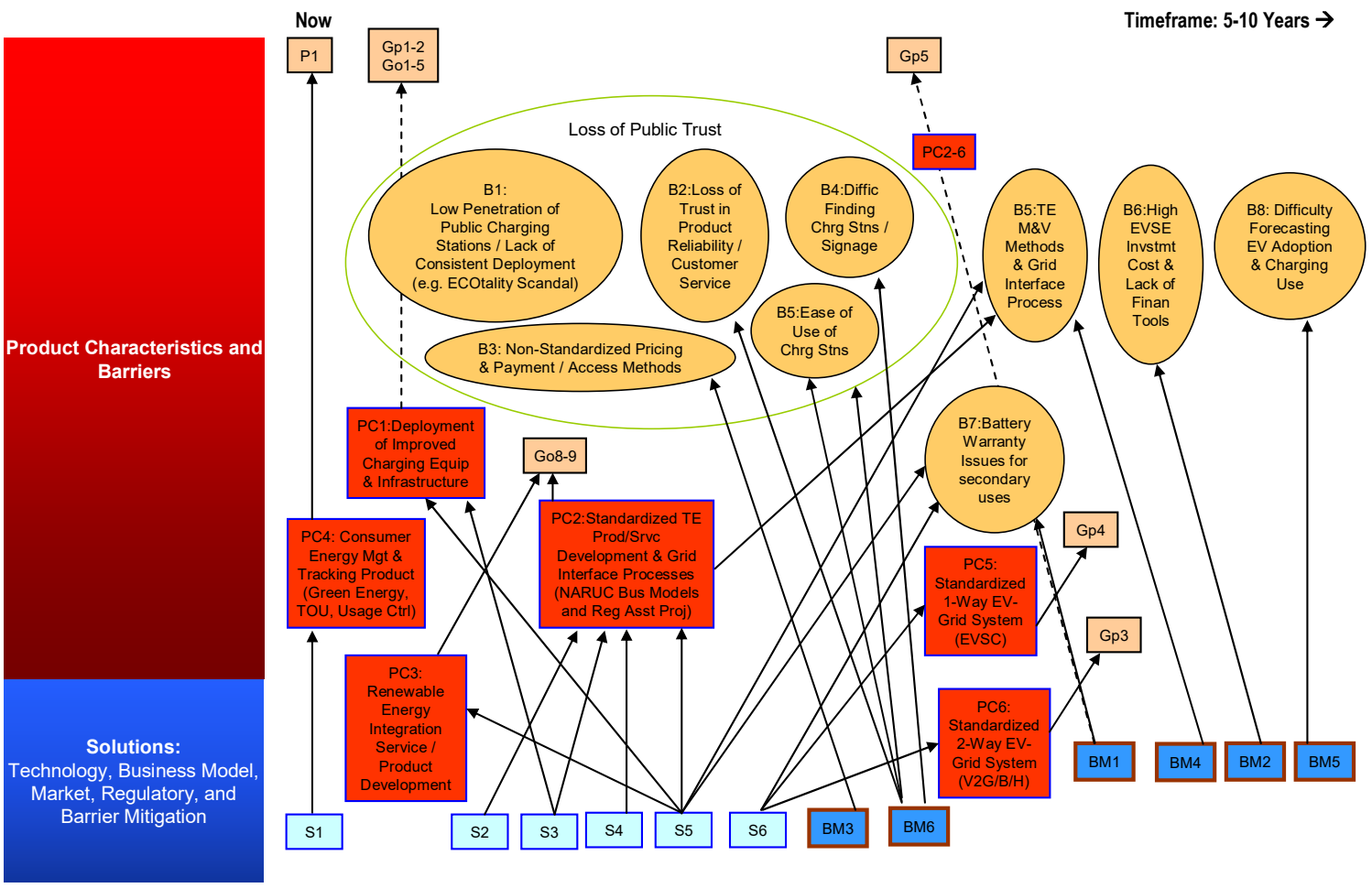

Figure 12: Integrated TRM Model: Electric Vehicle Charging - Part 2

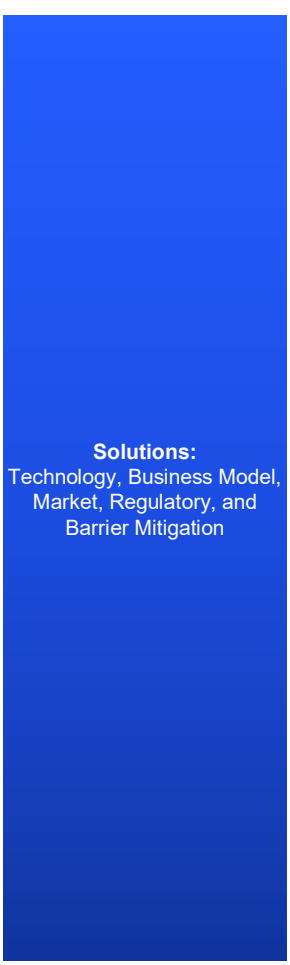

Now

Timeframe: 5-10 Years $\rightarrow$
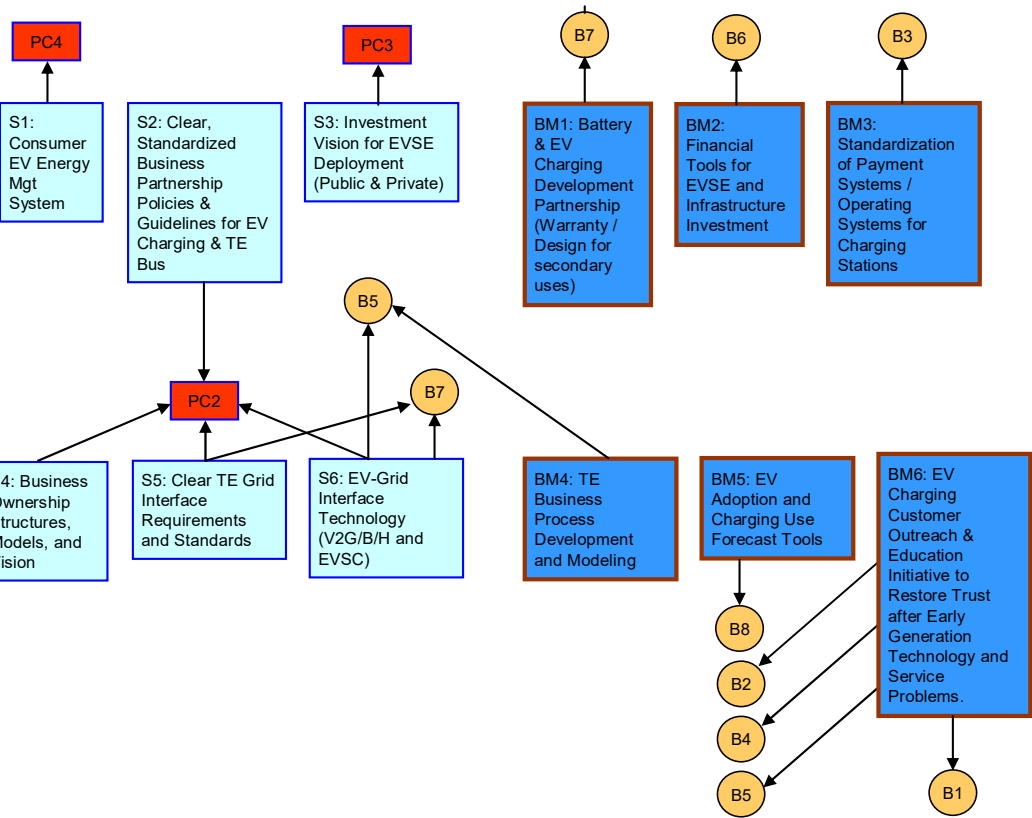

Figure 13: Integrated TRM Model: Electric Vehicle Charging - Part 3 
Part 2 of the general roadmap consists of the third and fourth layers, which starts with a continuation of the Product Characteristics and Barriers layer and then begins the initial portion of the Solutions layer. Part 3 is shown above.

Part 3 of the general roadmap consists of the fourth layer, which began in Part 2. After showing each of these three parts, a number of important facts about the overall roadmap are discussed below, as well as some ways to improve the organization of the roadmap. To make it easier to focus on specific aspects of the roadmap over shorter time horizons, the roadmap is further broken into version $\mathrm{A}$ and version $\mathrm{B}$ for each of the of the 3 parts. Version A reorganizes the roadmap with a Business and Regulatory Organizational Focus, while version B reorganizes the roadmap with a Consumer and Market focus. Additional details about the organization of the roadmap are provided in the next section.

Several key pieces of information can be seen from the above figures. Key stakeholders include consumers, businesses, government organizations (GO), and nongovernment organization (NGO), and regulatory agencies . Decisions can then be made regarding whether to focus first on specific user segments among these stakeholders or on a combinations of segments. Further decisions can be made regarding different options for ownership structure and primary profit mechanisms. Ownership structures include the possibility of consumers, utilities, or third-parties, such as energy service aggregators owning and/or operating EV charging equipment and services. Key profit mechanisms include the following: (1) Direct fees for vehicle charging and/or parking fees; (2) membership fees and fees for other bundled and premium services, such as internet access or auxiliary vehicle power hook-up fees; advertiser fees or fees

for consumers to opt-out of advertisements; ancillary service fees, which provide essential services to utilities, such as voltage and frequency regulation; or energy efficiency optimization contracts and energy aggregation contracts, which allow a network operator to manage and optimize energy use over a grid or micro-grid. Other profit mechanism or combinations of mechanisms are also possible, but these were the main mechanisms identified through conversations with experts who participated in data gathering workshops for this study. Options for financing and distribution methods related to each business model were also considered that were appropriate for each of these cases. Methods for financing EV charging equipment purchase include rebates and tax credits for consumers, on-bill financing through utility companies, and third-party owned equipment with a service lease, or charging as a service models. Additional details about each of these points discussed above are provided in section 7.3.3, under the discussion of business models and in Appendix 5, where each of the business model specifications are described.

The overall roadmap shown in Parts 1, 2, and 3 summarizes a great deal of information about the technology, business, and regulatory landscape facing the electric vehicle charging industry. However, because it summarizes so many factors in one place, this can make the roadmap look cluttered and difficult to read. Therefore, to make it easier to focus on specific aspects of the roadmap, the follow sections breaks each of the 3 parts into 2 sections. Section A shows a Business and Regulatory focused version of the roadmap. Section B shows Consumer and Market focused version of the roadmap. Each of these are show below as parts 1 through 3, sections A and B.

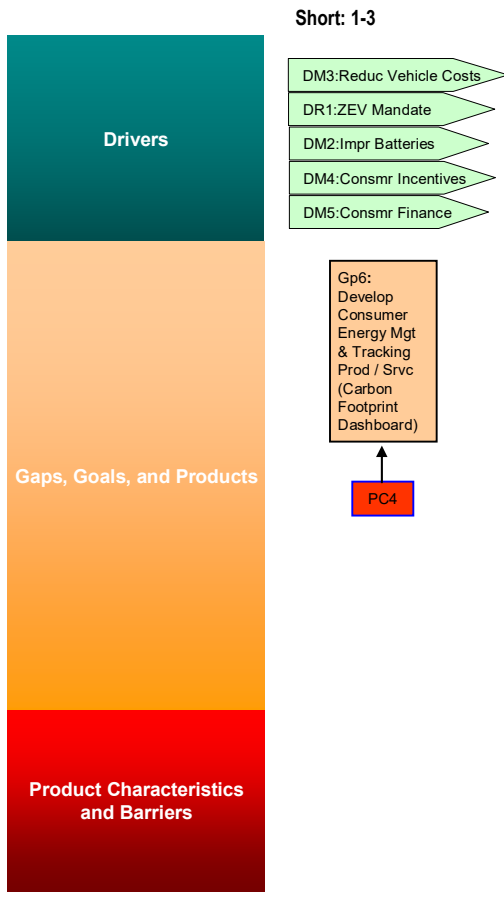

Medium: 4-6
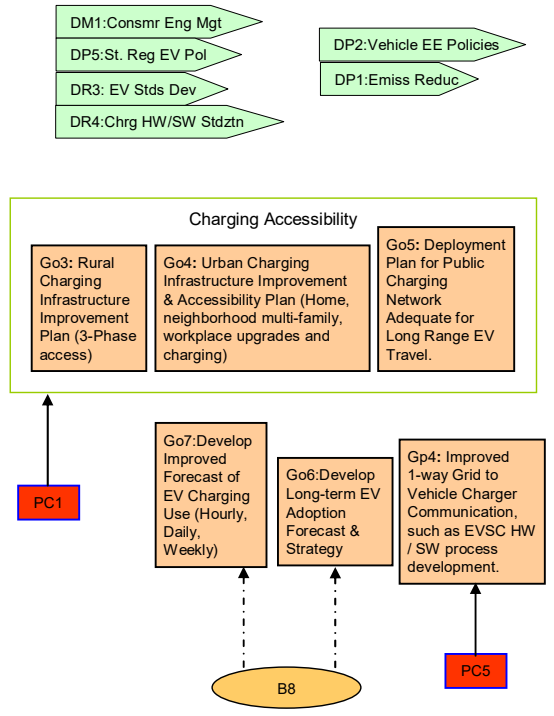

Figure 14: Integrated TRM Model: Electric Vehicle Charging - Part 1a
Long: $7-10$ Years $\rightarrow$

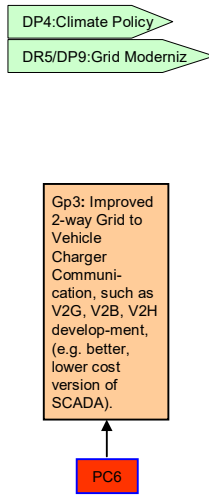


Part 1a of the general roadmap consists of the third and fourth layers, which starts with a continuation of the Product Characteristics and Barriers layer and then begins the initial portion of the Solutions layer.

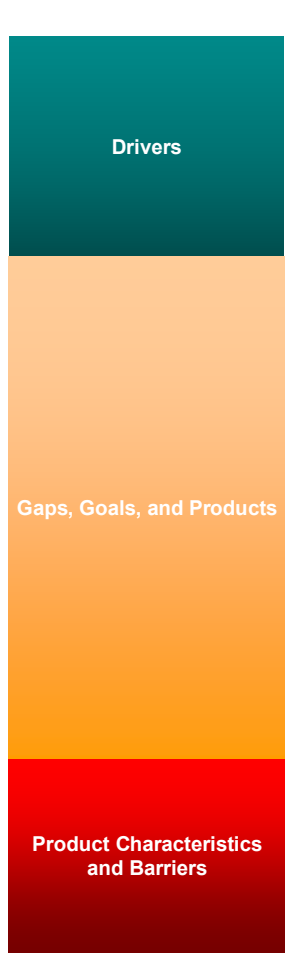

Short: 1-3
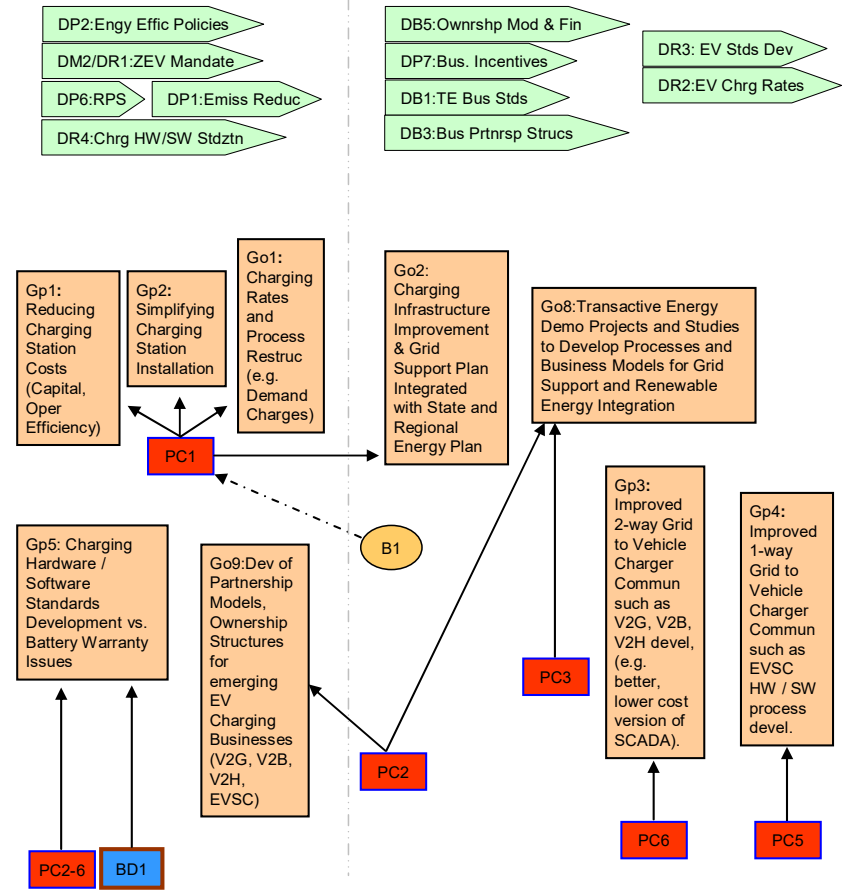
fourth layers, which starts with a continuation of the Product Characteristics and Barriers layer and then begins the initial portion of the Solutions layer.

Figure 15: Integrated TRM Model: Electric Vehicle Charging - Part 1b
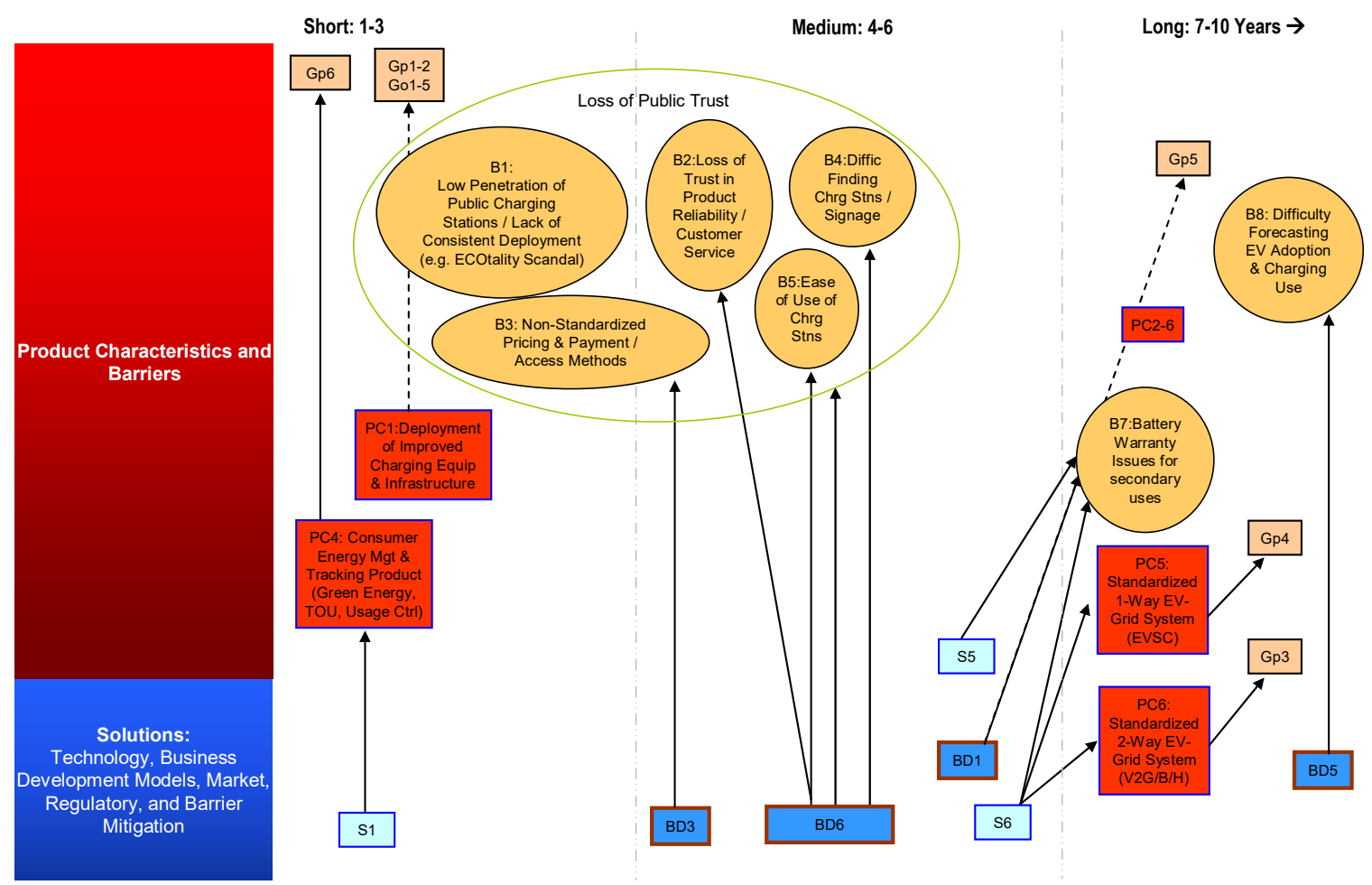

Figure 16: Integrated TRM Model: Electric Vehicle Charging - Part 2a 
Part $2 \mathrm{a}$ of the general roadmap consists of the third and fourth layers, which starts with a continuation of the Product Characteristics and Barriers layer and then begins the initial portion of the Solutions layer.

Part $2 b$ of the general roadmap consists of the third and fourth layers, which starts with a continuation of the Product
Characteristics and Barriers layer and then begins the initial portion of the Solutions layer.

Part 3a of the general roadmap consists of the third and fourth layers, which starts with a continuation of the Product Characteristics and Barriers layer and then begins the initial portion of the Solutions layer.

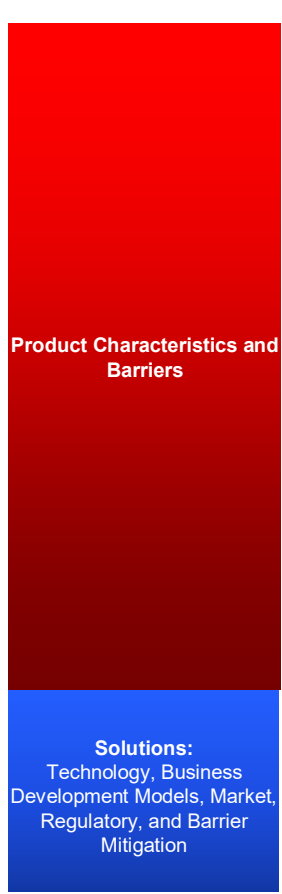

Short: $1-3$

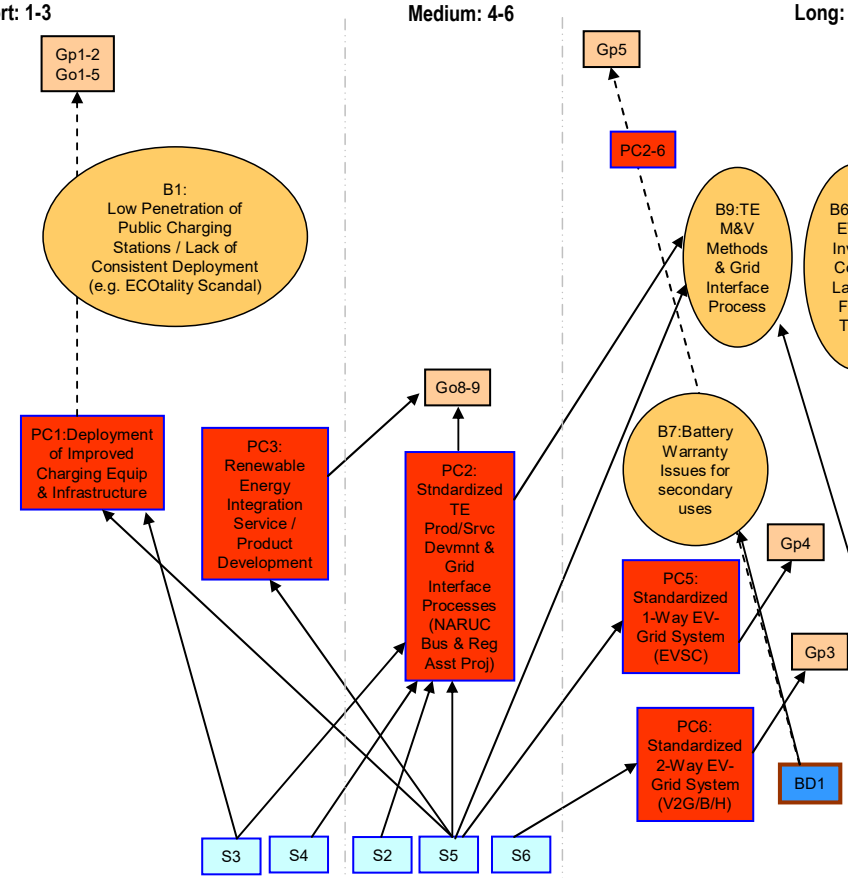

Figure 17: Integrated TRM Model: Electric Vehicle Charging - Part 2b
Medium: 4-6
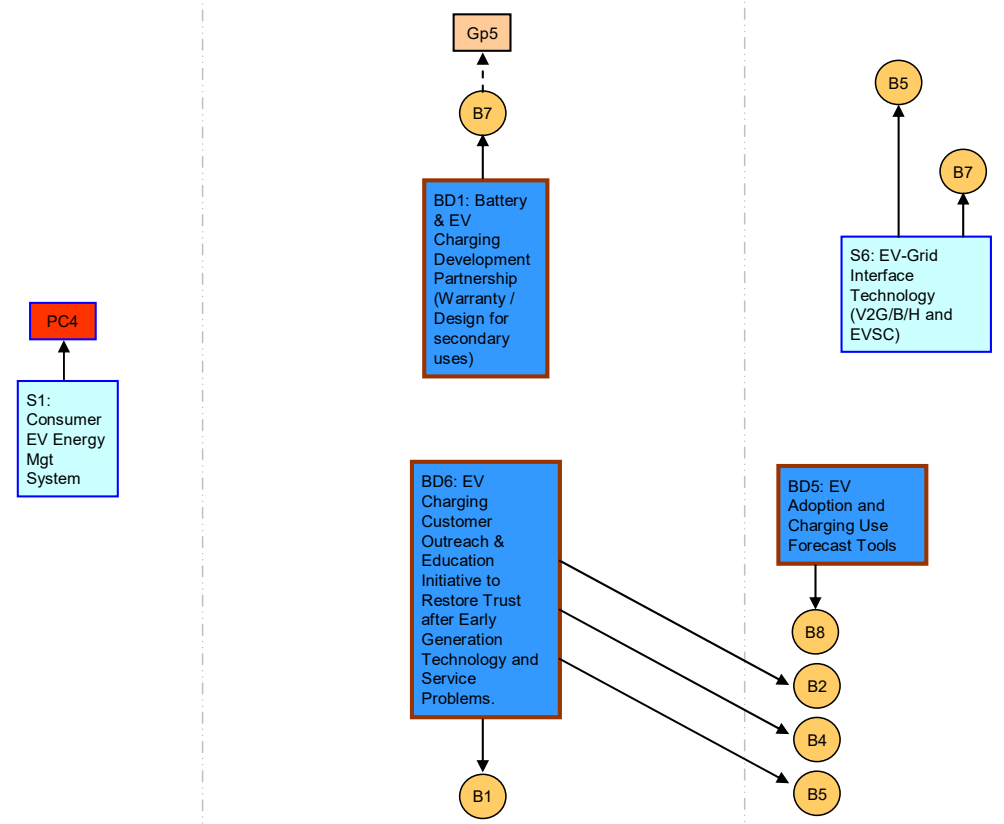

Long: 7-10 Years $\rightarrow$

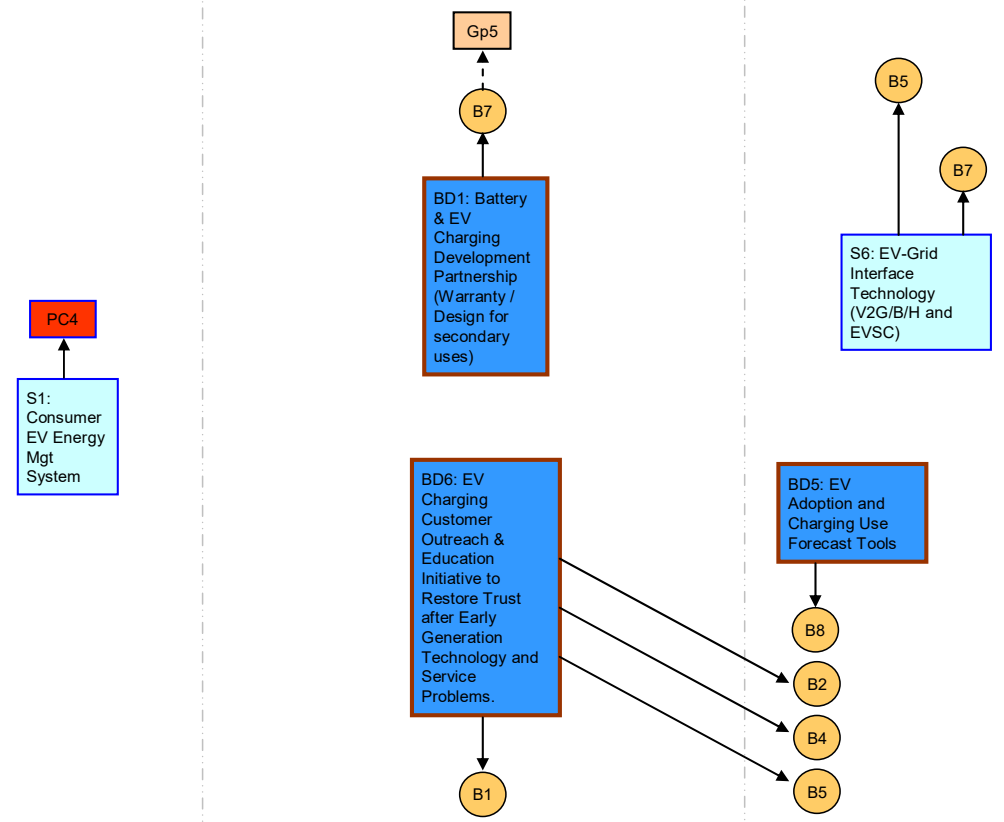

ong: 7-10 Years $\rightarrow$

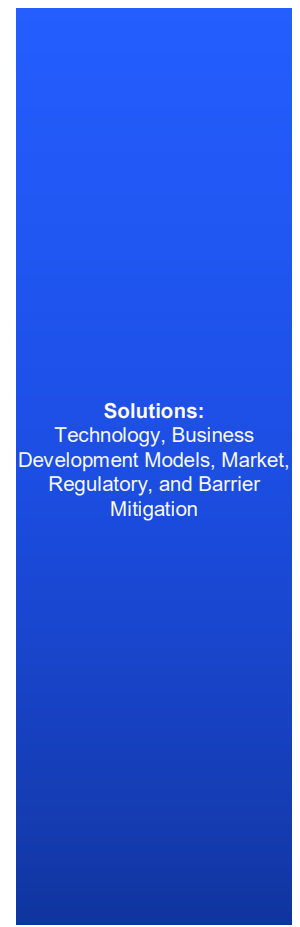

Figure 18: Integrated TRM Model: Electric Vehicle Charging - Part 3a 


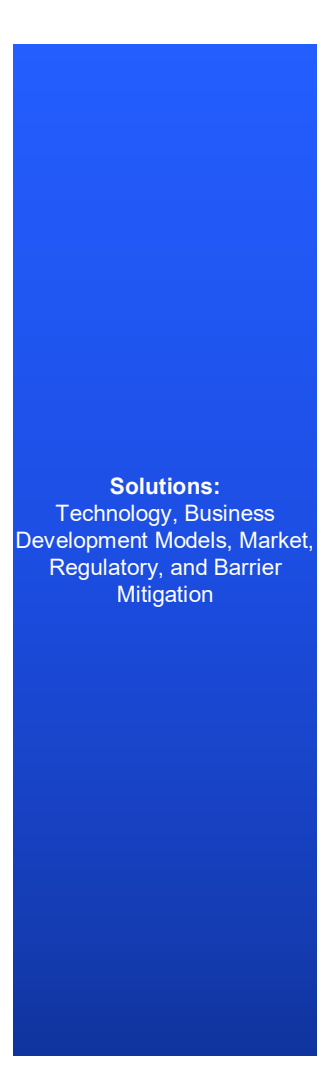

Short: 1-3

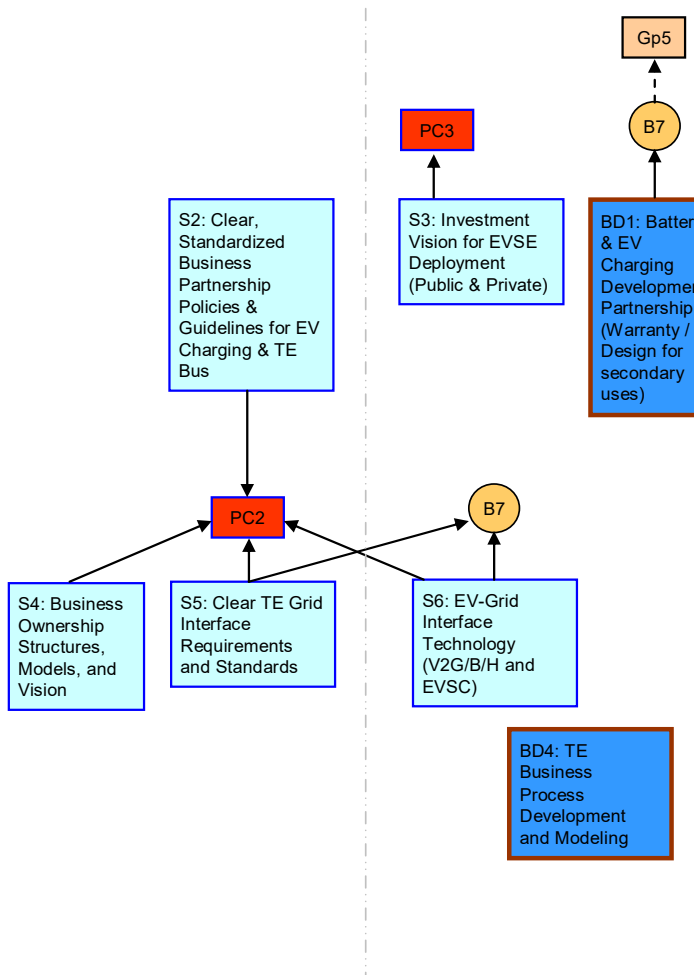

Medium: 4-6

Long: $7-10$ Years $\rightarrow$

Figure 19: Integrated TRM Model: Electric Vehicle Charging - Part 3b

Part $3 b$ of the general roadmap consists of the third and fourth layers, which starts with a continuation of the Product Characteristics and Barriers layer and then begins the initial portion of the Solutions layer.

\section{CONCLUSIONS, AND RECOMMENDATIONS}

The main outcome of this research is the development of a process to help integrate technology roadmapping with business modeling, as well as regulatory and policy planning, and to thus enable better understanding of opportunities for emerging technologies in emerging environments. This process is expected to be especially important for dealing with regulated industries, such as the utility sector, which has historically had one of the lowest rates of research and development investment of any major technology-based industry, only $0.25 \%$ of revenue [128]. The are many reasons for this, including common regulatory structures, and various justifications for such regulatory structures, as discussed in previous sections. However, the result of this investment pattern has clearly been a slow, careful deployment of technology, which has focused on durable, well-understood devices and systems, which have often been deployed and operated for decades at a time. While this may have had some favorable effect of protecting utility ratepayers from investing in risky or uncertain new technologies, it has also caused the industry to remain one that is still largely analog and manual in an age where many if not most other technologies are becoming digital and automated. To develop and successfully deploy critical new energy-related technology in the 21 st century, at a time of increasing concern and urgency over rising energy costs and environmental damage caused by current technology, careful planning will be required, and new methods which gracefully integrate technology, business, regulatory, and policy consideration into a holistic approach may prove extremely useful. Creating a framework to assist with such efforts is a primary aim of this research.

This research also focuses on the emerging smart grid industry, since smart grid technologies appear to have great potential to drive future innovation in the electrical utility sector. However, this framework could be applied to many other emerging technology and industry environments as well. But, new tools are needed to tailor the development process to a variety of unique requirements. This research offers one such set of tools and processes to achieve this goal.

A number of key conclusions have been described in different sections of this study and can now be summarized, along with recommendations for next steps. Contributions the research makes to the existing body of knowledge in this 
field are described in the next section, followed by limitations and assumptions. There was consensus that development of EV charging hardware and software standards (RD3) was extremely important from technology, business, and regulatory perspectives. Improved DC quick chargers (P3) were also important from a technology perspective, and development of clear, consistent standards would help enable these efforts, removing a key barrier to more wide-spread deployment. Creation of support systems and warranty services for advanced batteries (P2) was very important from technology, business, and market perspectives. There was consensus that regional planning visions on charger deployment should be developed that could help integrate with existing plans to reach environmental goals and emissions targets. There was a divergence of views on the development of partnership structures (G2) as well as incentives and financing for electric vehicle charging (G3). These were seen as important from the Business and Regulatory perspective, but less so from the Market perspective. Therefore, the recommendations for next steps based on this data would be to focus on hardware/software standards (RD3), quick charger development (P2), and deployment plans (BD2). Once these standards are developed and deployment plans are implemented, partnerships (G2) and incentives (G3) would then make sense to explore. The research then looks at overall a series of technology roadmaps that incorporate those issues and related challenges over an approximately 10 year horizon and looked at specific alternatives, such as various business model options, which could be used to address specific challenges at different points in that timeline.

Several types of roadmaps were created to examine different aspects of this research. First, an overall roadmap was created that showed the combined effect of business, consumer, regulatory, and market factors over the entire 10year time span of the roadmap. The roadmap showed many key elements that relate to ownership structure and primary profit mechanism for stakeholders involved in implementing aspects of the roadmap. These mechanisms included: Direct fees for vehicle charging and/or parking fees; membership fees and fees for other bundled and premium services, such as internet access or auxillary vehicle power hook-up fees; advertiser fees or fees for consumers to opt-out of advertisements; ancillary service fees, which provide essential services to utilities, such as voltage and frequency regulation; or energy efficiency optimization contracts and energy aggregation contracts, which allow a network operator to manage and optimize energy use over a grid or micro-grid. The roadmap was then broken into two parts. Section A shows a Business and Regulatory focused version of the roadmap. Section B shows Consumer and Market focused version of the roadmap.

\section{REFERENCES}

[1] O. H. Bray and M. L. Garcia, Technology Roadmapping: The Integration of Strategic and Technology Planning for Competitiveness. Portland, OR: PICMET (Portland International Conference on Management of Engineering and Technology), 1997.

[2] R. Phaal, C. Farrukh, and D. Probert, T-Plan: The Fast-Start to Technology Roadmapping - Planning your Route to Success. Cambridge: University of Cambridge, Institute for Manufacturing, 2001.

[3] R. Phaal, C. J. P. Farrukh, and D. R. Probert, "Technology Roadmapping - A Planning Framework for Evolution and Revolution," Technological Forecasting and Social Change., vol. 71, p. $5,2004$.

[4] C. Holmes and M. Ferrill, "The application of Operation and Technology Roadmapping to aid Singaporean SMEs identify and select emerging technologies," Technological Forecasting and Social Change, vol. 72, pp. 349-357, 2005.

[5] A. Nauda and D. L. Hall, "Strategic technology planning--developing roadmaps for competitive advantage," in Portland International Conference on Management of Engineering and Technology, Portland, OR, 1991, pp. 745-748.

[6] R. N. Kostoff, "Systematic Acceleration of Radical Discovery and Innovation in Science and Technology," Technological Forecasting and Social Change, vol. 73, p. 923, 2006.

[7] M. Rinne, "Technology Roadmaps: Infrastructure for Innovation," Technological Forecasting and Social Change, vol. 71, p. 67, 2004.

[8] E. Lopez-Ortega, T. Concepcion, and S. Viloria, "Strategic Planning, Technology Roadmaps and Technology Intelligence: An Integrated Approach," presented at the PICMET (Portland Internation Conference for Management of Engineering \& Technology), Portland, Oregon, 2006.

[9] S. K. Kassicieh, S. T. Walsh, J. C. Cummings, P. J. M. Whorter, A. D. Romig, and W. D. Williams, "Factors Differentiating the Commercialization of Disruptive and Sustaining Technologies," IEEE transactions on engineering management /, vol. 49, p. 375, 2002.

[10] R. N. Kostoff, R. Boylan, and G. R. Simons, "Disruptive Technology Roadmaps," Technological Forecasting and Social Change, vol. 71, p. 141, 2004.

[11] S. T. Walsh, "Roadmapping a Disruptive Technology: A Case Study The Emerging Microsystems and Top-Down Nanosystems Industry," Technological Forecasting and Social Change, vol. 71, p. 161, 2004.

[12] S. T. Walsh and J. D. Linton, "Infrastructure for Emergent Industries Based on Discontinuous Innovations," Engineering Management Journal - Rolla, vol. 12, pp. 23-32, 2000.

[13] R. Zurcher and R. N. Kostoff, "Modeling Technology Roadmaps," The Journal of Technology Transfer, vol. 22, p. 73, 1997.

[14] B. A. Vojak and F. A. Chambers, "Roadmapping Disruptive Technical Threats and Opportunities in Complex, Technology-Based Subsystems: The SAILS Methodology," Technological Forecasting and Social Change, vol. 71, p. 121, 2004.

[15] J. L. Bower and C. M. Christensen, Disruptive Technologies: Catching the Wave. Boston, MA: Harvard Business School Publications, 1995.

[16] N. Gerdsri, "An Activity Guide for Technology Roadmapping," Technology Analysis and Strategic Management, vol. 22, pp. 229242,2010

[17] M. Amer and T. U. Daim, "Application of Technology Roadmaps for Renewable Energy Sector," Technological Forecasting \& Social Change, vol. 77, pp. 1355-1370, 2010.

[18] H. Abe, T. Ashiki, A. Suzuki, F. Jinno, and H. Sakuma, "Integrating Business Modeling and Roadmapping Methods - The Innovation Support Technology (IST) Approach," Technological Forecasting and Social Change, vol. 76, pp. 80-90, 2009.

[19] D. Fenwick, T. U. Daim, and N. Gerdsri, "Value Driven Technology Road Mapping (VTRM) Process Integrating Decision Making and Marketing Tools: Case of Internet Security Technologies," Technological Forecasting and Social Change, vol. 76, pp. 10551077, 2009. 


\section{Proceedings of PICMET '16: Technology Management for Social Innovation}

[20] A. M. Lamb, T. U. Daim, and S. Leavengood, "Wood Pellet Technology Roadmap," IEEE Transactions on Sustainable Energy, vol. 3, pp. 218-230, 2012.

[21] I. J. Petrick and A. E. Echols, "Technology Roadmapping in Review: A Tool for Making Sustainable New Product Development Decisions," Technological Forecasting and Social Change, vol. 71, p. 81, 2004.

[22] S. T. Walsh, R. L. Boylan, C. McDermott, and A. Paulson, "The Semiconductor Silicon Industry Roadmap: Epochs Driven by the Dynamics between Disruptive Technologies and Core Competencies," Technological Forecasting and Social Change, vol. 72, pp. 213-236, 2005.

[23] S. Lee, S. Kang, and Y. Park, "Technology Roadmapping for R\&D Planning: The Case of the Korean Parts and Materials Industry," Technovation, vol. 27, pp. 433-445, 2007.

[24] Y. Kajikawa, O. Usui, K. Hakata, Y. Yasunaga, and K. Matsushima, "Structure of Knowledge in the Science and Technology Roadmaps," Technological Forecasting Social Change Technological Forecasting and Social Change, vol. 75, pp. 1-11, 2008.

[25] R. W. Galvin, "A Practitioner's Update to Roadmapping: From Sustainable to Disruptive Technologies," Technological Forecasting and Social Change, vol. 71, pp. 91-103, 2004.

[26] G. L. Huffman, C. C. Lee, S. Rolander, and J. T. White, "A Summary of the EPA's Fuel Cell Program Dealing with the Environmental Life Cycle Assessment," Energy Sources, Part B: Economics, Planning and Policy, vol. 1, pp. 67-74, 2006.

[27] S. Lee and Y. Park, "Customization of Technology Roadmaps According to Roadmapping Purposes: Overall Process and Detailed Modules," Technological Forecasting and Social Change, vol. 72, p. 567, 2005.

[28] N. Gerdsri, "An Analytical Approach on Building a Technology Development Envelope (TDE) for Roadmapping of Emerging Technologies," 2005.

[29] N. Gerdsri and D. F. Kocaoglu, "Applying the Analytic Hierarchy Process (AHP) to Build a Strategic Framework for Technology Roadmapping," Mathematical and Computer Modelling, vol. 46, pp. 1071-1080, 2007.

[30] N. Gerdsri, R. S. Vatananan, and S. Dansamasatid, "Dealing with the Dynamics of Technology Roadmapping Implementation: A Case Study," Technological Forecasting and Social Change, vol. 76, pp. 50-60, 2009.

[31] R. Phaal, C. Farrukh, and D. Probert, "Customizing Roadmapping," Research Technology Management, vol. 47, p. 26, 2004.

[32] T. Daim and T. Oliver, "Implementing Technology Roadmapping Process: A Case Study of a Government Agency," Technology Forecasting \& Social Change, vol. 75, pp. 687-720, 2008.

[33] K. R. Cowan and T. Daim, "Comparative Technological Roadmapping for Renewable Energy," Technology in Society, vol. 31, pp. 333-341, 2009.

[34] T. U. Daim, M. Amer, and R. Brenden, "Technology Roadmapping for Wind Energy: Case of the Pacific Northwest," Journal of Cleaner Production, vol. 20, pp. 27-37, 2012.

[35] T. Daim, T. Oliver, I. Iskin, and J. Kim, "Technology Roadmapping: An Efficient Tool for Driving Regional Technological Changes," in Sustainable Systems and Energy Management at the Regional Level, ed, 2012.

[36] T. Daim, D. Kocaoglu, N. Gerdsri, and I. Kockan, "Technology Development Envelope Approach for the Adoption of Future Powertrain Technologies: A Case Study on Ford Otosan Roadmapping Model," Journal of Transportation Systems Engineering and Information Technology, vol. 11, pp. 58-69, 2012.

[37] R. Phaal, N. T. M. H. Shehabuddeen, and P. Assakul, "Technology Roadmapping: Charting the Route Ahead for UK Road Transport," in Engineering Management Conference, 2002. IEMC '02. 2002 IEEE International, 2002, pp. 794-798 vol.2.

[38] R. Phaal, C. Farrukh, R. Mitchell, and D. Probert, "Starting-Up Roadmapping Fast," IEEE Engineering Management Review, vol. 31, pp. 54-60, 2003.

[39] O. Saritas and M. A. Oner, "Systemic Analysis of UK Foresight Results - Joint Application of Integrated Management Model and
Roadmapping," Technological Forecasting and Social Change, vol. 71, p. 27, 2004.

[40] M. Dissel, R. Phaal, C. Farrukh, and D. Probert, "Value Roadmapping: A Structured Approach for Early Stage Technology Investment Decisions," presented at the PICMET 2006: Technology Management for the Global Future, Istanbul, Turkey, 2006.

[41] R. Phaal, E. O'Sullivan, M. Routley, S. Ford, and D. Probert, "A Framework for Mapping Industrial Emergence," Technological Forecasting \& Social Change, vol. 78, pp. 217-230, 2011.

[42] R. Phaal and G. Muller, "An Architectural Framework for Roadmapping: Towards Visual Strategy," Technological Forecasting and Social Change, vol. 76, pp. 39-49, 2009.

[43] V. Thorn, F. Hunt, R. Mitchell, D. Probert, and R. Phaal, "Internal Technology Valuation: Real World Issues," International Journal of Technology Management, vol. 53, pp. 149-160.

[44] H. Martin and T. U. Daim, "Technology Roadmap Development Process (TRDP) for the Service Sector: A Conceptual Framework," Technology in Society, vol. 34, pp. 94-105.

[45] G. Hamel, Leading the Revolution. Boston, MA: Harvard Business School Press, 2000.

[46] A. J. Slywotzky, Value Migration: How to Think Several Moves ahead of the Competition. Boston, MA: Harvard Business School Press, 1996.

[47] A. J. Slywotzky, The Art of Profitability. New York, NY: Warner Business Books, 2002.

[48] H. W. Chesbrough, Open Innovation: The New Imperative for Creating and Profiting from Technology. Boston, Mass.: Harvard Business School Press, 2003.

[49] M. E. Porter, On Competition. Boston, MA: Harvard Business School Pub., 2008.

[50] M. E. Porter, The Five Competitive Forces that Shape Strategy. Boston, MA: Harvard Business School Publishing, 2008.

[51] H. Abe, T. Hirabayashi, F. Ishida, Y. Oku, M. Kado, and H. Sakuma, "Value Creation Framework of Business Modeling Methods for R\&D Outputs," presented at the PICMET (Portland International Conference for Management of Engineering and Technology), 2005.

[52] H. Abe, T. Hirabayashi, M. Kado, and H. Sakuma, "A New Framework of Business Modeling Methods for R\&D Outputs: Valuation and Communication Tools for Engineers, Managers, and Investors," presented at the PICMET (Portland International Conference for Management of Engineering and Technology), 2004.

[53] Y. Yasunaga, M. Watanabe, and M. Korenaga, "Application of Technology Roadmaps to Governmental Innovation Policy for Promoting Technology Convergence," Technological Forecasting and Social Change, vol. 76, pp. 61-79, 2009.

[54] Y. Zhou, "A Policy Dimension Required for Technology Roadmapping: Learning from the Development of Emerging Wind Energy Industry in China," presented at the PICMET 2011 Portland, OR, 2011.

[55] EEI, A Summary of FERC's Standard Market Design Tariff NOPR. Washington, DC: Edison Electric Institute, 2002.

[56] NPCC, "Northwest Wind Integration Action Plan," NPCC (Northwest Power and Conservation Council), Portland, OR 2007.

[57] K. Dragoon, "Lowest Cost Balancing Resources," ed. Portland: NPCC (Northwest Power and Conservation Council), 2011.

[58] B. M. Nickell, "Wind Dispatchability and Storage - Interconnected Grid Perspective," EERE (Energy Efficiency \& Renewable Energy Department) 2009.

[59] Energy Policy Act of 2005, 2005.

[60] BPA, What is RTO West? Portland, OR: Bonneville Power Administration, 2000.

[61] M. R. Milligan. (2011). Western Interconnection Energy Imbalance Market: Status and Prospects. Available: http://purl.fdlp.gov/GPO/gpo16356

[62] ColumbiaGrid, "Intra-Hour Transaction Accelerator Platform: I-Tap," ColumbiaGrid2009.

[63] L. Karwoski-Magee and D. Ruben, "The Charrette: An Interdisciplinary Academic Tool," Design Principles and Practices: An International Journal, vol. 4, p. 11, 2010. 


\section{Proceedings of PICMET '16: Technology Management for Social Innovation}

[64] W. Spencer and T. Seidel, "National Technology Roadmaps: The U.S. Semiconductor Experience " in 4th International Conference on Solid-State and Integrated Circuit Technology, 1995.

[65] A. Diebold, "Overview of Metrology Requirements Based on the 1994 National Technology Roadmap for Semiconductors," in SEMATECH (IEEE/SEMI 1995 Advanced Semiconductor Manufacturing Conference and Workshop), Austin, TX, 1994.

[66] P. A. Koen, "Technology Maps: Choosing the Right Path," Engineering Management Journal - Rolla, vol. 9, pp. 7-11, 1997.

[67] R. N. Kostoff and R. R. Schaller, "Science and Technology Roadmaps," IEEE Transactions on Engineering Management, vol. 48, pp. 132-143, 2001

[68] M. G. Kendall and B. B. Smith, "The Problem of Rankings," The Annals of Mathematical Statistics, vol. 10, pp. 275-287, 1989.

[69] H. A. Linstone and M. Turoff, The Delphi Method: Techniques and Applications. Reading, MA: Addison-Wesley Publishing Company, 1975.

[70] K. Brockhoff, "The Performance of Forcasting Groups in Computer Dialogue and Face-to-Face Discussion," in The Delphi Method: Techniques and Applications, H. Linstone and M. Turoff, Eds., ed Reading, MA: Addison- Wesley, 1975, pp. 291-321.

[71] T. L. Saaty, The Analytic Hierarchy Process: Planning, Priority Setting, Resource Allocation. New York; London: McGraw-Hill International Book Company, 1980.

[72] T. L. Saaty, "Axiomatic Foundation of the Analytic Hierarchy Process," Management Science, vol. 32, pp. 841-855, 1986

[73] T. L. Saaty, Fundamentals of Decision Making and Priority Theory with the Analytic Hierarchy Process. Pittsburgh, PA: RWS Publications, 2000.

[74] J. L. Salmeron and I. Herrero, "An AHP-Based Methodology to Rank Critical Success Factors of Executive Information Systems," Computer Standards and Interfaces, vol. 28, pp. 1-12, 2005.

[75] E. Geisler, "The Metrics of Technology Evaluation: Where We Stand and Where We Should Go from Here," International Journal of Technology Management, vol. 24, pp. 341-374, 2002.

[76] D. J. Hammerstrom, J. M. Gephart, and R. W. A. Pacific Northwest National Laboratory, "Smart Technology Brings Power to the People," Power Engineering International, 14(10):45-46, vol. 14, 2006.

[77] P. Fox-Penner, "Fix Utilities Before they Need a Rescue," Harvard Business Review, vol. 87, 2009.

[78] P. Fox-Penner, Smart Power: Climate Change, the Smart Grid, and the Future of Electric Utilities: Island Press, 2010.

[79] EPRI, "The Green Grid: Energy Savings and Carbon Emissions Reductions Enabled by a Smart Grid," Electric Power Research Institute (EPRI) 2009.

[80] R. J. Procter, "Smart Grid Inventory: A Report to the Oregon Public Utility Commission," Public Utility Commission of Oregon, Salem, OR2011

[81] T. L. Friedman, Hot, Flat, and Crowded: Why we Need a Green Revolution -- And How it Can Renew America. New York: Farrar, Straus and Giroux, 2008.

[82] EPRI, "Estimating the Costs and Benefts of the Smart Grid: A Preliminary Estimate of the Investment Requirements and the Resultant Benefts of a Fully Functioning Smart Grid," Electric Power Research Institute (EPRI), Palo Alto, CA 2011.

[83] S. M. Amin and B. F. Wollenberg, "Toward a Smart Grid," IEEE Power \& Energy, vol. 4, p. 66, 2006.

[84] M. Rawson and J. Sugar, "Distributed Generation and Cogeneration Policy Roadmap for California," California Energy Commission, Sacramento, CA 2007.

[85] A. Chuang. (2011). California Utility Vision and Roadmap for the Smart Grid of 2020: Final Project Report. Available: http://bibpurl.oclc.org/web/45441http://www.energy.ca.gov/2011publ ications/CEC-500-2011-034/CEC-500-2011-034.pdf

[86] CAISO, "Smart Grid Roadmap and Architecture," California Independent System Operator 2010

[87] J. Houck and W. Rickerson, "The Sustainable Energy Utility (SEU) Model for Energy Service Delivery," The Bulletin of Science, Technology \& Society, vol. 29, pp. 95-107, 2009.
[88] A. J. O'Donnell, Soul of the Grid: A Cultural Biography of the California Independent System Operator. New York: Universe, 2003.

[89] CMU, "Smart Grid Maturity Model: Model Definition: A Framework for Smart Grid Transformation," Carnegie Mellon University (CMU), Fort Belvoir, VA 2010.

[90] W. S. Humphrey, Managing the Software Process. Reading, MA: Addison-Wesley, 1989.

[91] J. R. Persse, Implementing the Capability Maturity Model. New York: John Wiley \& Sons, 2001.

[92] Public Utilities Regulatory Policy Act of 1978: Report to Accompany S. $2114,1978$.

[93] X. Fang, S. Misra, G. Yue, and D. Yang, "Smart Grid - The New and Improved Power Grid: A Survey," IEEE Communications, 2011.

[94] CEC. (2010). CERTS Smart Grid Demonstration with Renewable Energy Integration. Available: http://www.energy.ca.gov/2010publications/CEC-500-2010-FS/CEC500-2010-FS-005.PDF

[95] ISSGC, "Illinois Statewide Smart Grid Collaborative: Collaborative Report," Illinois Statewide Smart Grid Collaborative 2010.

[96] ISGI, "Illinois Smart Grid Initiative: Summary of Smart Grid Bnefits and Issues," Illinois Smart Grid Initiative (ISGI) 2008.

[97] M. Olken, "A Smart Grid Partnership: International Efforts in Korea and Illinois," IEEE Power and Energy Magazine, vol. 9, pp. 4-6, 2012.

[98] Staff Recommendation to Use Oregon Electricity Regulators Assistance Project Funds from the American Recovery and Reinvestment Act of 2009 to Develop Commission Smart Grid Objectives for 2010-2014, OPUC Order No. 11-172, 2011.

[99] A. Brown and R. Satler, "Smart Grid Issues in State Law and Regulation," Galvin Electricity Initiative 2010.

[100] FERC, "Assessment of Demand Response \& Advanced Metering: Docket AD06-2-000," Federal Energy Regulatory Commission, Washington, D.C. 2008.

[101] R. W. Galvin, K. E. Yeager, and J. Stuller, Perfect Power: How the Microgrid Revolution Will Unleash Cleaner, Greener, and More Abundant Energy. New York: McGraw-Hill, 2009.

[102] NIST, "NIST Framework and Roadmap for Smart Grid Interoperability Standards, Release 1.0," National Institute of Standards and Technology, Office of the National Coordinator for Smart Grid Interoperability, Gaithersburg, MD2010 2010.

[103] Xcel, "Xcel Energy Smart Grid: A White Paper," Xcel Energy, Boulder, CO 2010.

[104] D. James, "Xcel Energy's Smart Grid," Proceeding of the Solar Conference, vol. 5, pp. 2859-2869, 2008.

[105] PSPI, "The Pecan Street Project: Working Group Recommendations," Pecan Street Project, Inc. (PSPI), Austin, TX2010.

[106] C. A. Smith, "The Pecan Street Project: Developing the Electric Utility System of the Future," University of Texas, Austin, TX, 2009.

[107] B. McCracken, K. Rábago, and M. E. Webber, Pecan Street Project Smart Grids and Austin's Energy Future. Austin, TX: University of Texas at Austin: Environmental Science Institute, 2010.

[108] Pacific Northwest Electric Power Planning and Conservation Act: Report to Accompany S. 885, 1979.

[109] NPCC, Restructuring of the Electric Utility Industry: Implications for the Goals of the Northwest Power Act. Portland, OR: Northwest Power Planning Council (NPCC), 1994.

[110] D. J. Duann, B. Chen, I. National Regulatory Research, and C. National Association of Regulatory Utility, A Survey of Recent State Initiatives on EPACT and FERC Order 636. Columbus, Ohio: National Regulatory Research Institute, 1994.

[111] K. Rose, R. E. Burns, and R. J. Graniere, Research Report: Summary of Key state Issues of FERC orders 888 and 889. Columbus, $\mathrm{OH}$ : National Regulatory Research Institute, 1997.

[112] K. W. Costello and R. E. Burns, Regional Transmission Organizations and the Coordination of Regional Electricity Markets: A Review of FERC Order 2000. Columbus, Ohio: National Regulatory Research Institute, 2000.

[113] U. S. Congress, Energy Policy Act of 1992: Public Law 102-486-Oct. 24, 1992. Washington, DC: US Government Printing Office, 1992. 


\section{Proceedings of PICMET '16: Technology Management for Social Innovation}

[114] H. Prem and N. Raghavan, "Building a Technology Roadmap in High Performance Computing in the Indian Context," presented at the PICMET 2005: A Unifying Discipline for Melting the Boundaries, Portland, OR, 2005.

[115] C. Wooster, "Encouraging Technology through Legislation: A Study of the Development of Cogeneration Facilities after the Enactment of the Public Utilities Regulatory Policies Act," 1988.

[116] R. Schaller, "Technological Innovation in the Semiconductor Industry: A Case Study of the International Technology Roadmap for Semiconductors (ITRS)," 2004.

[117] C. Cleveland and C. Morris, Dictionary of Energy. Amsterdam; London: Elsevier, 2005.

[118] L. Karwoski-Magee and D. Ruben, "The Charrette: An Interdisciplinary Academic Tool," Design Principles and Practices: An International Journal, vol. 4, pp. 11-21, 2010.

[119] P. Newman and C. Leverhant, "The Fuzzy Front End - Technology Identification, Staging, and Maturation: Where the Battle is Often Lost Without Firing a Shot," presented at the PICMET, Portland, OR, 2001.

[120] W. Kempton, "Automobiles: Designing the 21st century fleet," presented at the Seattle V2G Technical Symposium, Seattle, WA, 2005.

[121] R. Wells, R. Phaal, C. Farrukh, and D. Probert, "Technology Roadmapping for a Service Organization," Research technology management., vol. 47, p. 46, 2004.

[122] G. Rouse and J. Kelly, "Electricity Reliability: Problems Progress and Policy Solutions," Galvin Electricity Initiative2011.

[123] J. Jenkins, J. Bauman, and J. Bissonette, "Renewable Energy Standard " Powering Oregon's Future 2007.

[124] B. Shively and J. Ferrare, Understanding Today's Electricity Business, 4.0 ed. San Francisco, CA: Enerdynamics, 2008.

[125] C. Cramer, Thomas Edison. San Diego, CA: Greenhaven Press, 2001.

[126] M. Filippini, "Are Municipal Electricity Distribution Utilities Natural Monopolies?," Annals of Public and Cooperative Economics, vol. 69, p. $157,1998$.
[127] S. Insull and W. E. Keily, Central Station Electric Service: Its Commercial Development and Economic Significance. Chicago, 1915.

[128] NSF, "Funds for Industrial R\&D as a Percent of Net Sales of Companies Performing Industrial R\&D in the United States," National Science Foundation (NSF), Washington, DC 2010.

[129] L. Fox, Enron: The Rise and Fall. Hoboken, N.J.: Wiley, 2003.

[130] J. Casazza, Understanding Electric Power Systems: An Overview of the Technology, the Marketplace, and Government Regulation: John Wiley \& Sons, 2010.

[131] S. Coll, The Deal of the Century: The Break Up of AT\&T. New York: Atheneum, 1986.

[132] A. Nauda and D. Hall, "Strategic Technology Planning - Developing Roadmaps for Competitive Advantage," presented at the PICMET 1991, Portland, OR, 1991.

[133] ODOE, "Summary of Oregon's RPS " Oregon Department of Energy2007.

[134] C. Willyard and C. McClees, "Motorola's Technology Roadmap Process," Research Management, pp. 13-19, 1987.

[135] C. Holmes and M. Ferrill, "The Application of Operation and Technology Roadmapping to Aid Singaporean SMEs Identify and Select Emerging Technologies," Technological Forecasting and Social Change, vol. 72, p. 349, 2005.

[136] E. Bardach, A Practical Guide for Policy Analysis: The Eightfold Path to More Effective Problem Solving, 3rd ed. New York, N.Y.: Chatham House Publishers, Seven Bridges Press, 2009.

[137] V. Elmer and A. Leigland, Infrastructure Planning and Finance: A Smart and Sustainable Guide. New York: Routledge, 2013.

[138] F. Ishida, H. Sakuma, H. Abe, and B. Fazekas, "Remodeling Method for Business Models of R\&D Outputs," in PICMET (Portland International Conference for Management of Engineering and Technology), Istanbul, Turkey, 2006, pp. 708-714. 